SLAC - PUB - 4404

Detober 2987

(I)

\title{
DEVELOPMENT OF A LOW NOISE PREAMPLIFIER POR THE DETECTION AND POSITION DETERMINATION OF SINGLE ELECTRONS IN $A$ CERENKOV RING IMAGING DETECTOR BY CEARSE DJVISION*
}

\author{
E. SPENGER, P. COYIE, D. WILLLMS \\ Univeroity of California, Santa Crus, CA 05064
}

$$
\text { CONF-871006--17 }
$$

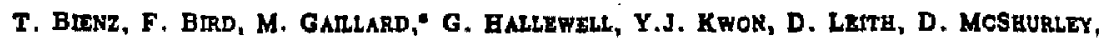

G. OXOBY, B. RATCLIF, P. RENENG, D. SGRULTZ, S. SHAPRO, N. TOGE,

Stonford Linear Aceelentor Center, Stanford Univernity, Slanford, CA Dssos

D. Caldweil, A. LU, E. Yetha

Univerrity of Caltiomia, Santa Barkare, CA osion

SLAC-POB--4404

B. Meanows, M. Nússanum

Univerrity of Cineinnati, Gineinnati, OH 158t1

DE88 003259

\section{Abatract}

A proxoplifier baving 500 dectrons noles (nans) has been developed for the detection and locetion of aingle electroms in a CRID detector at the SLD. A tingle ehannel contains preamp, RC-CR shoper, ealn adjustmest, drives, and calibration citcuitry. Noise and linearity mevurements uve presented.

\section{Introduction}

This paper will deweribe the low molwa electronica naed to detect ningle photodectrom in a Cerenkor Ring Imaging Dlector (CRID) ${ }^{1}$ being builh for the SLD opectrometer at the SLAC Linear Collider. The principle of operation of a CRD relies on optienily focursing the Cerentor light produced by selativistic chergod particles pasaling through gaseous or liquid rediators onto a photon detector. The sedius of the circle of Cerenkov light is a measure of the Cerentor angle, which in turn is a mesure of the velocity of the particle. The relotionwhip between the velocity and the momeatum of the particle permit an extimake of the particle'b tomen.

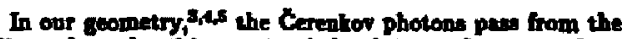
rediater through a thin quarts window into our detector, where they are converted to aingle photoulsetrens by the photo ionization of Letratis dimethylaminoethylase (TMAE); $\triangle 0.19$ componeat of our detector gas. Withlo this detector, the elestrons drift at conitant velocity to a proportional cenne wire plane where they are detected.

Por optimum perfarmance, 2 CRD munt necomatruet the poojtion of the converted photon in all three dimenvions. Thio will result in optimizing the spatial revolution of the ivolatisd photoelection. Mingy of the errom inherent wo Cerenkow angle meunirement buve already boan redued by carefol thoien of geometry and detector segmeatation. These are, however, courtes of errot much as diffusion, ehromatte sberrations, and momentum amenring which contribule en iredocible cotal er. sor of approximately $1 \mathrm{~mm}$ to thit meanusement. Thus, there - thitle to be gined by reducing other cource of error vignifi. cantly below this value.

- Work supported in part by the Depurtment of Enercy, eeparacts DE-ACOS-76SFO0515 and DE-ATOS-70ER70023, and by the Natlonal Science Foundaclon, Grants PHYBS-12148 and PHYB5-19808.

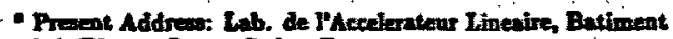
200, F91405 Oraty, Ceder, Drance.
Two condingles of the point of arifis of the photoclec: tron are recorded os the wire eddrean at which the electron it counled and its drift time. The propontiond chember employed an the detector for the CRID" ham a wixe epocing of 3.175 $\mathrm{mm}$, correspondiag to a top hat" resolution (o) of $0.82 \mathrm{~mm}$. The maximum drin diatance of our burel CRID is $1288 \mathrm{~mm}$. If the time menparowent corropondiog to this dintence in seg-

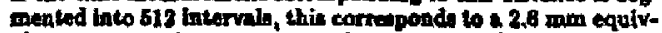
clent nefmentation, esentially the exme as in the wire opacins dimention wheo a $10 \%$ acale ofiset for a poutble decrease in deif velacity is allowed.

The third coordinnte measurement, that corresponding to the convernion depth of the photon within the difft volume, is meanured by the une of charge divinion along the resistive anode rense wire of the proportional chember. It is this mesurement which makes the mout evere demund on the electronies, as bere too, wo requite 1-2 zom renolutio': Oux wires, resiative carbon filmonents $7 \mathrm{~mm}$ in dimmeter, are $10 \mathrm{~cm}$ long, reaulting th a requirement of $2 \%$ oputial recolution for the meenarement along the wire.

The aignal to noise ratio is the crocial eriterion in the deAlga of the cherge division electronia. We intend to rus the cul gain of the proportional chamber wo that an average photoelectron oignal will produce $2 \times 10^{3}$ disctrons. This choice is not completely apblerey, wis with more convantional chasmbers, in thit = CAID uthe TMAE an it photolonizing gas must consider minimizins photon feedbeck in entting the gas gain.

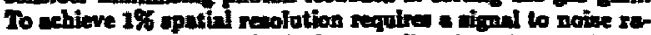
tio of at tewt 100:1, which then limplias that the maximpun acceptable noite lavel be beld below 2000 electrons (rmi).

\section{a. The Circult}

The circuit showa in Fig. 1 ho bees menured to have a noise figure of 500 eleetroins (rms), predominantly due to our chaice of the front end BFD92 MOSFET, ous eircuil RC-CR

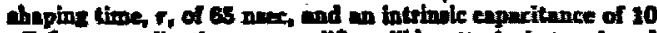
pF. In our applietion, an minplifier will be atinched at each end of the resiative anode wise, thos, on edditionnl parallel noise conse vis. the theresel of Johnmon noise of the redintive wive mual be added in puadrature to the umplifier noice. At a r.pf $65 \mathrm{nwec}$, the $40 \mathrm{kn}$ wire has approximutely oso electrons (r) soise for a total solne figare of about 1100 electrons (mm)

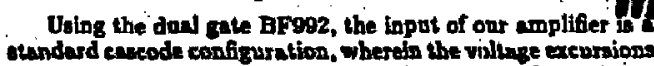
of the find trangintar drain are limited by the necerd itransistor. The total open loop gin of the presmp is about 600 . 


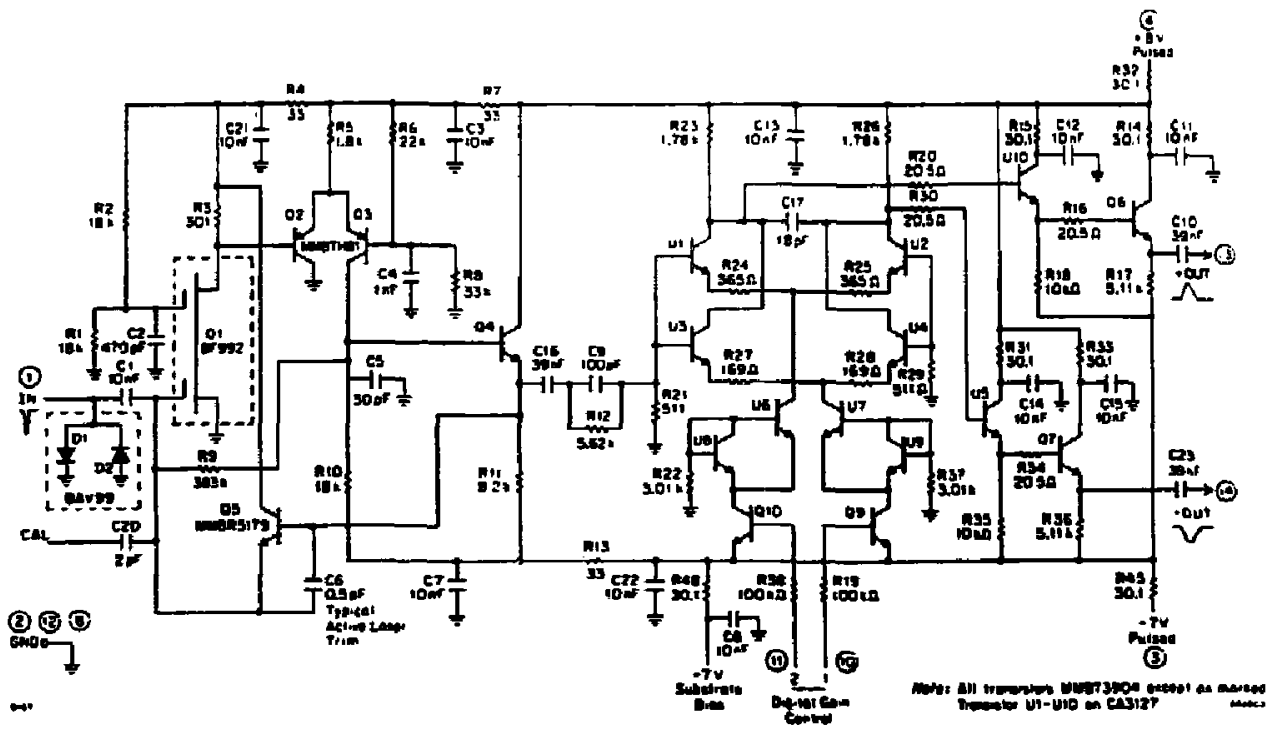

Fis. 1. Sebemutic diugram of the MOSFET preamplifer.

Charge to roltare copversion is afiected by the parallel combiantion of the $0.5 \mathrm{pF}$ expacitor $\mathrm{C} 6$ and the exitier-baec $\mathrm{Ca}$ -


capecitance of about $1.6 \mathrm{pF}$. In production, $\mathrm{CB}_{6}$ will be lever trimened to provide ain uajormity, Trantirtor Q5 is necesGary to limit the voltage excurion of $\mathrm{Cr}$ at the detection of minimum ionizing particle, which might have ar much as 1000 times the churge of our normal aingle electron simal. The CRID preamplifier mut heve s fast recovtry from ouch dignals and to this end, the base emitter junction of this omall reometry n-p-n trandistor is placed between the first stage output and input. The fint etage is bined so that when the output exceeds 1.4 volk in response to a laree input eignel, Q5 turm on and cancels the input aignal. The non-linetr tranaistor junction capacitance contribution to the feodbuck capacitance in minimired by being beck biesed by ane diode trop and by the collector tie io the poitive tail.

There are twoshaping cirtuits which afeet the performance of the emplitier. The freh, the pole sero network (Co \& R12), cancels the exponential decay of the etes fonction prenmplifier output. This is followived by RCCA ahaping (CO I R12j|R21;

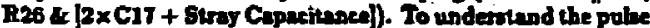
hape characletibtice of our amplifier, it theoretical response to a inpot impolse has been compared to data talen viing a nnmber of orir MOSFET prototypes. We have modelled otur preamplifier's transfer function with four-time constants, carre ponding to input tage fitezation, pole exo, RC-CR integration und RC-CR diffuentiation. We have also inventigated the vimplibeation of this tranfer function when only the RC-CR integrition and alferantintion time constants are considered. The MOSFET date were then fit to both of the above response functions. The remles of the fit we showe in Figs: $2(c)$ and 2(d). The foll exptestion fits the dats quite well, while the aimplified expesaion to reanable errept for the polre tail, where contributions from the bos time contente, ignored in the approimution, mite a aignificant contribution to the overAl pule shape

Compoter aimulation of our chrcult oniag SPICE" revended that followins the puasege of a minlmum ionixing particle have ins $32 \mathrm{pC}$ of ehare, or about 1000 time the normal uingle

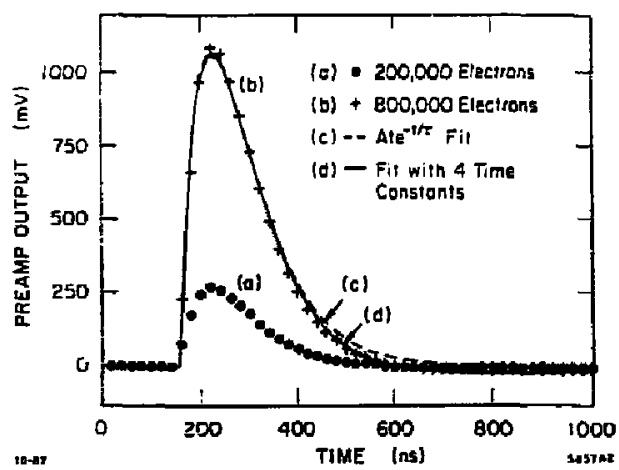

Fit. 2. (a) MOSFEI preapp pube dusp for $2 \times 10^{5}$ electrons. (b) MOSFET preamp pule chape for $8 \times 10^{5}$ electrons. (c) Fit of the datn to the form Ale $e^{-1 / r}$. (d) Fit of the data wa a Four time comutant expresion.

phovolectron signal, the pulse returned to the base line in bout 300 nex, allowing the delection of a second pulse on a slowly varying bese line. Figure 3 jlluatrates this SPICE simulation of the anplifier recovery. The ajgnel collection time is 100 nsec. Preliminey messuraments of this recoyery time are in progreas, and ate not incosuistent with the SPICE simulation.

Input protection for the cireult is provided by the BAV99 diodes, and by Zenes diade vithin the BF002. Test made in the laboralory have ahown that the circuit is not destroyed by the pulse produced when 5 KV utored on $210 \mathrm{nF}$ capacitor it repeatedly shortened to ground and input to the circuit through $200 \mathrm{n}$. 




Fig. 3. SPJCE timulation of the amplifier recovery for $32 \mathrm{pC}$ of input charge.

The pramplifier will include a provision for gain adjustment. Gen control is achieved simply by building two pouible pathways for the signal on each prearap, each baving a different electronic gain. We car chooue to mend the singl through either peth, or both, for three powible find rais choices.

The CRID preamplifith will be whjext to a very wide range of input eharte: a vriation of almont four ordere of megnitude. To minimite moighborins channel erowetelk over this wide dyaamic resre, the iadividud amplitien will be packaced a tingle channel by bridn. The PC bourd prototype of this circuit is uhown in Fig. 4. Is dimantiont are abont $8.8 \mathrm{~cm} x$ $5 \mathrm{~mm}$. This will eliminate on-board crontall and allow for the interpoing of conductive ecreens to reduce radiative croestall. We have found that the mavimom efiect of a large toput rignal of chont $10^{\circ}$ electron on its nevreat neightor is equindeni to - vignal of about $16 \times 10^{6}$ electron. It can, hawever, be reduced by an edditions factor of 15 with interpated crovended

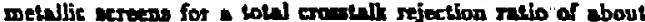
$60 \mathrm{~dB}$. The mesarued crovitall b non linear, trom oipall les then $10^{\circ}$ electrons it it se-lidible.

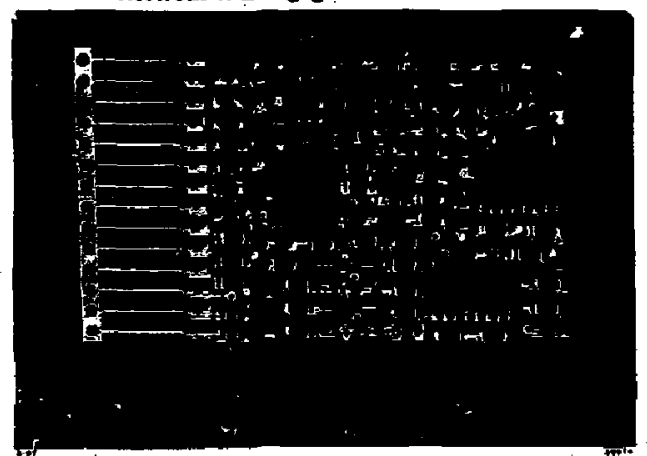

Eis. 4. Pholecreph of the MOSTEr pramp PC boind proto type.

The bybrids will uee aurface movent technolo gy. Bpace conviderations permit this wehnique and the eont toptientions are extremely truoreble, 4 the fabrieation yield will be high. The ane of marice moust componente, hermetieally cenled and lested, wo increases reliability. Under present iovertigation is the we of a eemi-custom mopolithic thip incorporating most of the tircult elements discused sbove. This chlp, prilenged as - surface mount device would further reduce the complexity of the bybrid and increase reliability.

Circtitry for the celibrition of the electronics, necesoary to ochieve $1 \%$ charge diviajon resolution, is provided. A digitally puleed voltege step erented by a DAC cettles in 10 naec and is presented to the amplifer input. The elrcuit is nhown achemetically in Fis. 8 und reides on each of the prenopplifier bybrida. During the fabricstion procens a active ?tar trim of $\mathbf{R} 43$ provides an accurtle trim of the charse injected.

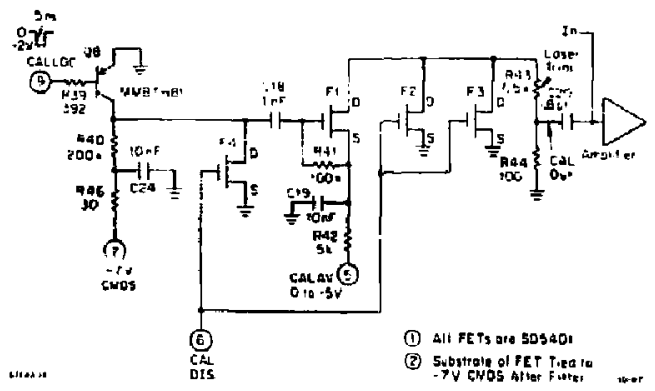

Pig. 8. The ealibration elreult for the MOSFET preamp.

Ohe channel of rendout electronica is cotoptied of e prenmplifier, ohoper, cuin oteze, driver, and a unalos memory unjt. Figure 6 th e echematie roprentation of the readous chennel in which the meential lature are highlighted. The anslog ampling of the waveform thtite on the use of the SLAC Microntore chlp (AMU). 10 This ehip is an arrey of 256 wampling calle, all of whowe inputa are tied torether throus a serite pate in exh. Sixteen AMU ehipa ane combined into an eight chasnel bybrid (HAMU)" with each changel werviced by two AMU ehipa. This provide ivitel of 512 anpolins eell per ebannel.

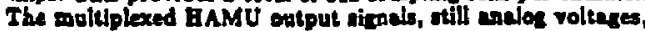
are trannmitted vis an optied fber link to 19 bit ADCo outaide of the opectrometer fron. Prombion for a DC ealibration of the BAMU butern in ineluded in the rytem. Momte Carlo simt-

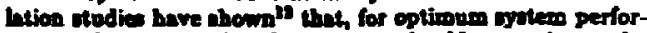
mence, the preamplifier ahopine time chould epproxionate the time between eamplen in the AMU. Thw, the thexlonum elertron drift time divided by $\mathbf{B} 12$ anmple determine the prenmplifer obepipe time $r$, and, therefore, the thermel aoise in and the muximum pulue puir recolution of our mytem.

A mother bourd conlaining 186 anplifers mates with the ctrip line inputa from the detector vis ero incertion force sockate. Pulod power î zeneraled on the mother bourd for deliver to the hybrids. Locel enercy atorage in the form of large cepactiors is provided nearby. Surtuet mount components are need where errilable for the calibration circuitsy on the mother botard.

A the tional to noine tatio in of primury importance in the devim of this wytem, the eliminution of noise tources dots not and with the datign of the prenupifier. The mechanical deim of the detector mint be coordinnted with the layout of the pe bourd mounting of the emplifien to provide 1 weparate. inoleted clene rigmal ground to curround the senvitive low noive electronic. 


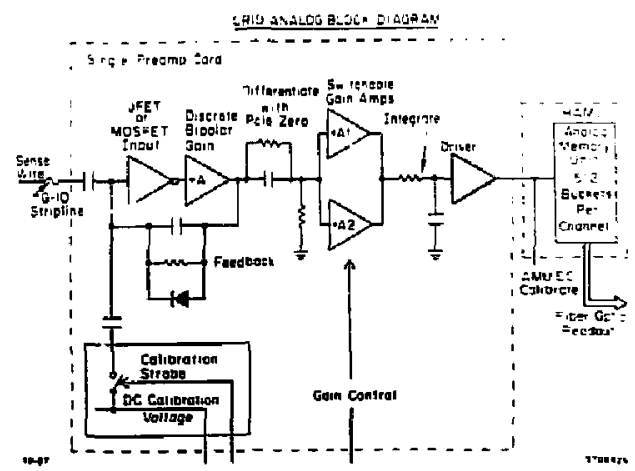

Fig. 6. A block diagram of the CRID andog readout channel.

\section{The Meanuremento}

Substartial progreas has been made in determining the gain, linearity, noise levels, eronstalk and overdrive performance of the CRID preamplifier through a rtudy of nine prototype preamplifers.

Eight of the prototype amplitien are variations of the circuit thown in Fig. I uing the Phillips BFog2 dual gate MOS. FET, logether with other unfuct-mount components in a layout suitable for hybridiation. The ninth prototype utilizes. J309 JFET in the cirtuit configuration thown in Fig. 7. It hes been used principally lo: noise comparion purposes, although a hybrid preamplifer usins a JFET lnput trassistor is under active consideration. Note alo thet the shaping time of the JFET prololype in EO nsec.

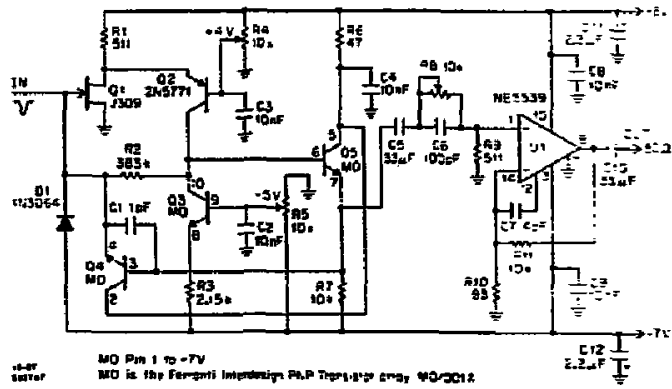

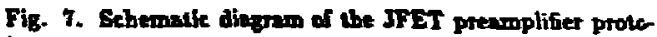
type.

A lasgely autamated preamplifer teat orotem has been constructed for menourementa of mplifier cherge gain and noise levels. A LeCroy 2961 Image Chember Analyzer (ICA), operating at 50 MHz, with unity gain, 11 bit resolution and 320 time alies, provides high-speed sampling of the preamplifier output pulbe, while the combination of the CAMAC pactaged DAC and a charge injection chrexil allow the preamplitier ta be studied ower the full ragge of inpot charge experted in operation:

In these tests, the outputs of the preamplifiens have been spprocimately matehed, wins $50 \mathrm{n}$ driver, to the $2 \mathrm{~V}$ dynamic range of the ICA. Since the HAMU also hes $2 \mathrm{~V}$ range, the total syslem chargeto-voltage gain is typical of that expected in CRID operation. Figures 2(a) and 2(b) show ICA digitizinge of preamplifier output pulses correaponding to 200,000 and 800,000 electrons respetively. Figure 8 shows histograms of the variation of preamplifer output voltage with input charge for the three aelectable gain settings of the BF992 MOSFET prololype. These characterigties were obtained automatically by applying the CAMAC DAC voltage to the charge injection eapacilor in series with the input. The alope ol each line gives the charge to voltage conversion gain. In the surpple of eight MOSEET prototypes, the variution of gain at the arme tetting is les the $2 \%$. In fuet, the range of lines amplification extends considerably beyond thet shuwn in Fis. 8, with pretmplifer autput enturetion occurring only for charges in excess of ${ }^{10}$ electrons, even with the highest gain ectting. This range is far beyond that expected in the single photoclectron pules height apectrum.7

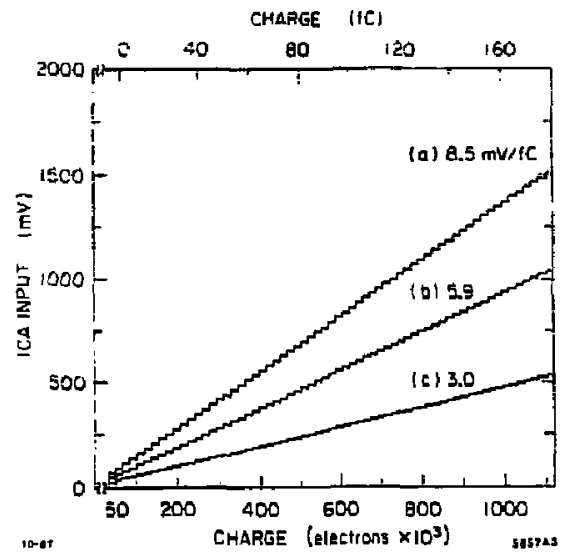

Fig. A. Fistogram of preamp output voltege ve. input charge for the three amplifier gain settings.

To mesure the input noive chaneterintics of the MOSFET and JFET preamplifies under various canditions of input loading, the charge injection capecitor in rewoved, and parallel tapacitance, resistance, or CR combinations are added between the amplifier input and ground. The emplified input noise is menaured with the ICA, roing a soltware-defined "gate width". The gate width is chooen to be gix times the amplifer ahaping time, a measured from an independent fit to the output pulse thepe wing osingle time contrant. Thb interval contains about $98 \%$ of the pulse output charge. For the MOSFET and JFET prototypes, t is meturted to be 65 mete [Fig. $2(c)\}$ and 47 nuec, and the gete width are set to 390 naec end 300 asec sepectively. The equivalent noise charge (ENC) in electrons is eiven by

$$
\langle E N C\rangle=\frac{\left[\sigma_{V}^{2}(A M P)-\sigma_{F}(I C A)\right]}{G \cdot E}
$$

where or (AMP) and ov (ICA) reopectively are the standard deviations $(\mathrm{mV})$ of the pedeatal diatributions seen in the ICA with and without the implifer connected, based on comparable auple of at leat 1,000 measurements; $G$ is the charge gain of the amplifer (in $\mathrm{mV} / \mathrm{sC}$ under the eppropriate input loading conditions) and $e$ is the electron charge is femtocoulombs.

Figures 9 and 10 thow the variation of ENC with added capacitance and/or resistanes for the MOSFET and JFET 


\section{DISCLAIMER}

This report was prepared as an account of wort sponsored by an agency of the United States Government. Neither the United States Government nor any agency thereof, nor any of their employees, makes any warranty, express or implied, or assumes any legal liability or responsibility for the aceuracy, completeness, or usefulness of any information, apperatus, product, or process disclosed, or represents that its use would not infringe privately owned rights. Reference hercin to any spe. cific commercial product, process, or service by trade name, trademark, manufacturer, or otherwive does not necessarily constitute or imply its endorsement, recommendation, of favoring by the United States Government or any agency thereof. The views and opinions of authors expresed berein do not necessarily atate or reflect those of the United States Government or any agency thereof. 


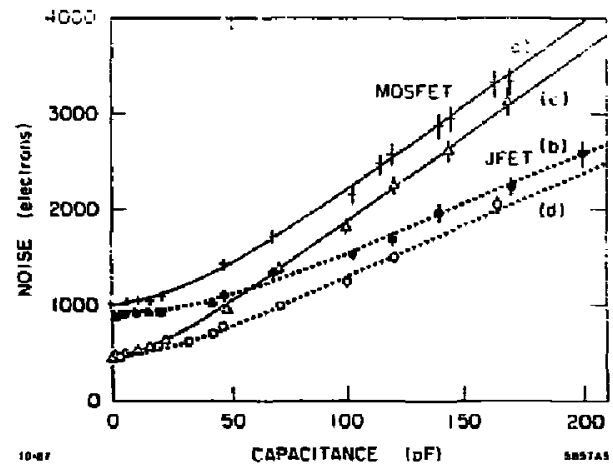

Fig. 9. Variation of (ENC) with added input capacitance for: (a) The MOSFET presmplifier wilh $10 \mathrm{~K} \Omega$ resistance to ground. (b) The JFET preamplifier with $10 \mathrm{Kn}$ redistance to ground. (c) The MOSFET preamplifer with no additional resiatance. (d) The JFET preamplifer with no additions re sistance.

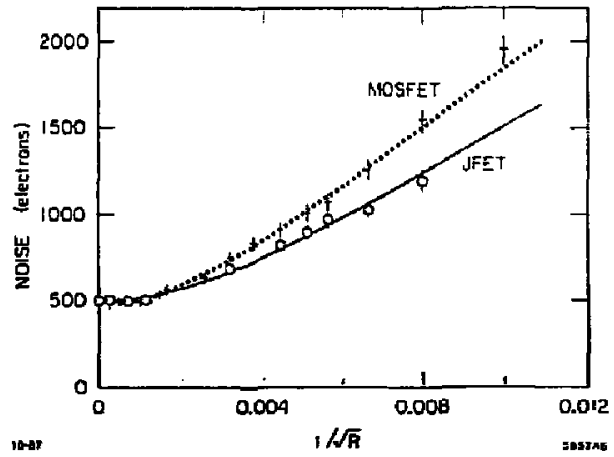

Fig. 10. Variation of (ENC) with added input resistance for: (a) The MOSFIT preamp. (b) The JFET preanp.

preamplifer prototypes. Our mearurements confirm thet either input tranoistor wovid give seceptable noise performance for our application. Bolh amplifien bave about $\mathbf{5 0 0}$ electrons (rms) noite with no added reviotance or capacitance and 1100 ind 950 electrons (rms) repectively for $10 \mathrm{pF}$ of assumed chamber eapacitance, and an input rwistance of $10 \mathrm{kn}$ characteristic of $10 \mathrm{~cm}$ long $7 \mu \mathrm{m}$ dinmeter carbon nense wire. In Fig. $Q(c)$ and $Q(d)$ the voibe measurement was made without the 40 kn input renlotance. In the vample of eight MOSFET prolotypes, the variation of ENC under identical load conditions between amplifiers was found to be about 10\%. Ap. proximalely half of the moasired ENC differente between the MOSFET and JFET preampo b e result of the nlight diference in shaping times of the two prolotypes. The mersurements (a) and (b) of Fig. 9 hove beca ft to a general FET amplifier noibe model' ${ }^{13}$ aring the MiNUTT ${ }^{14}$ ottine program

$$
\begin{aligned}
\left(E N C_{i}^{\prime}\right. & =\frac{2.71 \mathrm{~B}}{c}\left(\frac{k T \mathrm{r}}{2\left(R_{I N T} \| R_{C H}\right)}+\frac{e J_{G T}}{4}\right. \\
& \left.+\frac{k T R_{E C}\left(C_{I N T}+C_{C H}\right)^{2}}{2 \mathrm{~T}}+\frac{A_{J}\left(C_{I N T}+C_{C H}\right)^{2}}{2}\right)^{\frac{1}{3}}
\end{aligned}
$$

where $t$ is the alectron charge $\left(1.602 \times 10^{-10} \mathrm{C}\right)$ and $\mathrm{k}$ is the Boltzmann constant $\left(1.381 \times 10^{-23} \mathrm{JK}^{-2}\right) . R_{C H}$ and $C_{C H}$ represent the chnmber resiatance and capacitance respectively: in the amplifier tests these are rimalated by added resiatance and capecilunce-the date points for the ft. $T$ is the sbsolute temperature $(-208 \pm S K)$ while $T$ i the mensured amplifier ahaping time. The free parameter in the fit are $C_{\text {rNT }}$ and $\boldsymbol{R}_{\boldsymbol{I N T}}$ \| $\boldsymbol{R}_{\boldsymbol{C H}}$ representing the intrinnic caparitance of the $\mathbf{m}$ plifier and the resistance in parallel with its input (in operation the parallel rum of the amplifier fatrinalic resintance and the 10 In ense wire), $I_{G}$ and $R_{R C}$, the FET pale cursent and equiv. lent noice resintance; and $A_{f}$, the $1 / f$ noike (Volt $\left.{ }^{2}\right)$. For each amplifier, a goad fi $\left(x^{2} / D F\right.$ of $\left.\sim 1\right)$ wa obtained with tinal parameter vines within the ranges expeeled. $\boldsymbol{R}_{\mathrm{INT}} \| \boldsymbol{R}_{\mathrm{CH}}$ was fit to within $10 \%$ of the $40 \mathrm{Kn}$ resitance used to aimulate the carbon cenve wire, while the intrintic tapacitance of the amplifiers was found to be between $S$ and $10 \mathrm{pF}$. The tranaistor parameters were sloo found to be within their expected ranges. ${ }^{15} R_{C H}$ for the JFET and MOSFET were found to be nbout $50 \mathrm{n}$. This was confirmed for the BFOP2 by an independent mesnorement of its traneconductunce $(22 \mathrm{mS})$ at $1 \mathrm{MHz}$ with drain curreat of $6 \mathrm{~mA}$. Similarly, the fit values for $A_{f}$ and $I_{G}$ were found to be in the rangea $10^{-13}-10^{-12}$ Volt' and $2 \times 10^{-11}-10^{-1}$ A respectively.

The final amplifier conforaration under trventigation is one which will eventually allow the use of a nemi-eustom monolithic integrated eircuit erray containing sbout $70 \%$ of the circuit clementa described above. Schematically then, the eroplifier hybrid will be comprised of the low noise inpul transistor; the calibration circuit, and the wemi-custom element. To imple ment this ides, the prenmplifer cireuit uaing the JFEI input was found to be uperior to that uning the MOSFET, as the dual gate of the MOSFET does not perform as well as a aingle transistor when designing solely with NPN trangintors.

\section{Conclusion}

A presmplifier using o low noise dual gate MOSFET front end has been designed, built and tented. It performs well, having a noise level of abant 500 dectrons rus at a shaping time of 65 moec. It is linear over its entire nonge 10 better than 1\%. It has been used on out most recent CRID detectos for the menrurement of single photoeletron spectra. These results are being presented in a separate contribution to this oymosium. A second prenmplitier uring a JFET front end has been desigmed, brilt and tested and bes been found to perform as well as the fint.

\section{MOSFET Prenmp specifieation}

Fint stange:

1. Input Signal (vingle p.e)

2. Feedback Copacitor

3. Equivalent Input Naise

4. Signal Dynomic Range

5. Inpul Connection

6. Input Capacitance

7. Input impedance

Pout Amplifier/Shaper:

1. Gain (nominal gain = 1)

2. Alternative Gein Setting

3. Pole Zero Cancellation

4. RC - CR Shaping

5. Gain Degradation

$$
\begin{aligned}
& =32 \mathrm{fC}\left(2 \times 10^{3} \mathrm{e}^{-}\right) \\
& =\text {sbout } 1.6 \mathrm{pF} \\
& =500 \mathrm{e}^{-}(\mathrm{rms}) \mathrm{g} 65 \mathrm{~ns} \mathrm{~T} \\
& =10^{3}-10^{6} \text { electrons } \\
& =51 \text { ip Line on } \mathrm{G} 10 \\
& =<10 \mathrm{pF} \\
& =600 \mathrm{~N} \text { (measured) }
\end{aligned}
$$

$$
\begin{aligned}
& =1.6 \text { Differential } \\
& =\times 1, \times 2, \times 3 \\
& =e^{-1 / T_{0}} T_{0}=580 \mathrm{~ns} \\
& =T_{0 i t}=\tau_{\text {ind }}=85 \mathrm{~ns} \\
& =1 / \mathrm{e}(\mathrm{RC}-\mathrm{CR})
\end{aligned}
$$


Sygtem Considerations:

1. Packaging

2. Pins

3. Power

4. Power Duty Cycle

5. Pulke Pair Redution

6. Calibration Aceuracy

7. Linearity

B. Crosstalk

9. Calibratr Modes

I0. Grin Senvitivity to PS Voltage $=1 / 500$

1]. Strobe Power Recovery $=54$ ab offel from bese

12. Environment

line after $400 \mathrm{ps}$

$=40^{\circ} \mathrm{C}$

\section{Acknowledemente}

We would like to thank M. Cavalli-Sforza for uneful diseussians early in this project and $\mathrm{J}$. VeVre for continued discueaions relating to our eystem requirements.

\section{Heference:}

1. J. Seguinat and T.Ypsilantis, Nucl. Inst. Meth. 142, 377 (1977).

2. M. Breidenbach, IEEE Trans. Nucl. Sci. NS-33, 46 (1986).

3. V. Ashford th al, IEEE Trans. Nucl. Sci. (1967), SLACPUB 1405 .
4. V. Ashford at al. IEEE Tratis. Nucl. Sci. NS-34, 499 (1987).

5. V. Ashford at al. Presented at the XXIII Lnt]. Conf. on High Energy Physics, Berteley, CA (1986), SLAC-PLB 1064.

6. J. VaVra ef al Paper submitted to the 1987 IEEE Nucl. Sel. Symp., SLAC-PUB 1432.

7. F. Bird at al. IEEE Trans. Nucl. Sci. NS-s3, 261 (1986),

8. A Vledimireacu et Sl Spice Version 2G, University of Califoraia, Eerkeley, CA (1981).

g. J.T. Walker, Soo-IK Choe, 5. Shapiro, R. Lareen, IEEE Trans. Nucl. Sci. NS-32, 616 (1985).

10. D. Freytag, J.T. Walker, IEEE Trane Nucl. Sti. NS-32, 622 (1985).

11. D.R. Freytag, G.M. Haller, H. Kang, J. Wang, IEEE Trang. Nuel. Sei. NS-33, Bi (1986).

12. For more information oee S. Shapiro, N. Spencer, B. Rat clif, S. Yellin, CRID MEMO \#31, 1987 (unpublished).

13. See C.F.G. Delaney Electronjes for the Phyticiat , Ellis Horwood Ltd., Chichester, UK (1980), p. 261.

14. F. James and M. Roos, MINUIT, CERN Computer CenLer Write-up D506, CERN Progsam Library (1877).

15. F. Maniredi, Leeture presented at the 1985 IEEE Nuclear Science Symposium, San Francisco, CA (unpublished). 